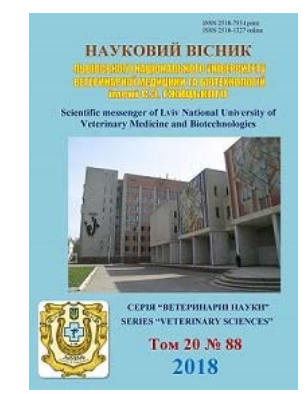

Науковий вісник Дьвівського національного університету ветеринарної медицини та біотехнологій імені С.3. Гжицького

\author{
Scientific Messenger of Lviv National University \\ of Veterinary Medicine and Biotechnologies
}

ISSN 2518-7554 print

doi: $10.32718 /$ nvlvet8807

ISSN 2518-1327 online

UDC 636.237.21.082.251:619:618

\title{
Fagotherapy of cows mastitis as an alternative to antibiotics in the system of obtaining environmentally safe milk
}

\author{
Yu.V. Horiuk \\ Article info \\ Received 13.08.2018 \\ Received in revised form \\ 03.09 .2018 \\ Accepted 04.09.2018 \\ State Agrarian and Engineering \\ University in Podilya, 13, \\ Schevchenko Str., Kamianets- \\ Podilskyi, Khmelnytskyi region \\ 32300, Ukraine. \\ Tel.: +38-097-661-79-64 \\ E-mail: goruky@ukr.net
}

State Agrarian and Engineering University in Podilya, Kamianets-Podilskyi, Khmelnytskyi region, Ukraine

Horiuk, Yu.V. (2018). Fagotherapy of cows mastitis as an alternative to antibiotics in the system of obtaining environmentally safe milk. Scientific Messenger of Lviv National University of Veterinary Medicine and Biotechnologies, 20(88), 42-47. doi: 10.32718/nvlvet8807

The global market for environmentally friendly food products has been developing rapidly in recent decades and is becoming an alternative to the consumption of harmful, environmentally hazardous products. The prohibition of the use of chemically-synthesized traditional veterinary drugs or antibiotics for prophylactic purposes is one of the requirements for conducting an organic dairy farm. The purpose of the work is to review literature on the possible use of bacteriophages for the treatment of mastitis of cows with the aim of obtaining ecologically safe milk. Mastitis is among the most common diseases of cows. The particular importance in the onset of the disease is the microbial factor. A wide range of microorganisms that can cause mastitis, and the significant spread of these bacteria, make complete eradication of mastitis unlikely. Drugs are used for the treatment of mastitis, which in most cases contain antimicrobial substances such as antibiotics, sulfanilamides, nitrofurans etc. Despite the great success in treating antibiotics, there are a number of negative side effects, including the emergence of antibiotic-resistant microorganisms. An obvious alternative to the use of antibacterial drugs in the treatment of cows mastitis is the use of highly effective ecologically safe drugs based on raw materials of plant, mineral and animal origin. Currently, considerable experience in the successful use of phages for the treatment of bacterial infections has been accumulated in foreign and domestic medical and scientific practice. The use of bacteriophages in compliance with generally accepted principles can achieve a significant therapeutic result. The antibacterial effect of bacteriophage drugs is due to the introduction of the phage genome into a bacterial cell, followed by its reproduction and lysis of the infected cell. Phages released into the environment as a result of lysis bacteria re-infect and lysis of other bacterial cells, acting until the complete destruction of pathogenic bacteria in the inflammatory site. Bacteriophages have several advantages: specificity of action, absence of inhibition of normal microflora and allergic reaction. In addition, a weighty argument in favor of expediency of clinical use of bacteriophages is almost complete absence of side effects, and, consequently, contraindications.

Key words: organic products, mastitis, antibiotic-resistant, bacteriophages.

\section{Фаготерапія маститу корів, як альтернатива антибіотикам в системі одер- жання екологічно безпечного молока}

Ю.В. Горюк

Подільський державний аграрно-технічний університет, м. Кам'янецьь-Подільський, Хмельницька обл., Украйна

В останні десятиріччя світовий ринок екологічно чистих продуктів харчування бурхливо розвивається $і$ стає альтернативою споживання шкідлиих, екологічно небезпечних продуктів. Однією з вимог ведення органічного молочного господарства $є$ заборона застосування хімічно-синтезованих традииійних ветеринарних лікарських препаратів або антибіотиків із профілактичною метою. Мета роботи - провести огляд літератури щодо можливого використання бактеріофагів для лікування маститів корів 3 метою одержання екологічно безпечного молока. До числа найбільш поширених захворювань корів відноситься мастит. Особливе значення у виникненні захворювання має мікробний фактор. Широкий спектр мікроорганізмів, які можуть викликати мастит, $i$ значне поширення иих бактерій роблять повне викорінення маститів малоймовірним. Для лікування маститів використовують препарати, які в більшості своїй містять антимікробні речовини, такі як антибіотики, сульфаніламіди, нітрофурани тощєо. Незважаючи на великий успіх при лікуванні антибіотиками, виникає ряд негативних побічних впливів, в тому числі поява антибіо- 
тикостійких мікроорганізмів. Очевидною альтернативою застосування антибактеріальних препаратів при терапї маститів корів є використання високоефективних екологічно безпечних лікарських засобів на основі сировини рослинного, мінерального та тваринного походження. Донині в зарубіжній $і$ вітчизняній медичній $і$ науковій практиці накопичено значний досвід успішного використання фагів для терапіі бактеріальних інфекцій. Використання бактеріофагів при дотриманні загальноприйнятих принципів дозволяє домогтися значного терапевтичного результату. Антибактеріальний ефект препаратів бактеріофагів обумовлений впровадженням генома фага в бактеріальну клітину з подальшим його розмноженням і лізисом інфікованої клітини. Фаги, ияо вийшли в зовнішнє середовище в результаті лізису бактерії, повторно інфікують і лізують інші бактеріальні клітини, діючи до повного знищення патогенних бактерій у вогнищі запалення. Бактеріофаги мають ряд переваг: специфічність дї, відсутність пригнічення нормальної мікрофлори і алергічної реакції. Крім того, вагомим аргументом на користь доцільності клінічного застосування бактеріофагів є практично повна відсутність побічних ефектів, а отже, і протипоказань.

Kеу words: органічні продукти, мастит, антибіотикостійкість, бактеріофаги.

\section{Вступ}

В останні десятиріччя світовий ринок екологічно чистих продуктів харчування бурхливо розвивається і стає альтернативою споживання шкідливих, екологічно небезпечних продуктів (Nuttavuthisit and Thogersen, 2017). Частка господарств, що постачають натуральну сільськогосподарську продукцію стає дедалі більшою (Krystallis and Chryssohoidis, 2005; Ahrendsen and Bielik, 2016). Ринок цих товарів швидко розширюється не тільки в розвинутих, а й у країнах, що розвиваються, в тому числі і в Україні.

Органічна продукція - це продукція, отримана в результаті сертифікованого органічного виробництва. Характерною особливістю органічного сільськогосподарського виробництва $є$ наявність суворо регламентованих умов та правил щодо належного утримання тварин, їх годівлі, лікування, профілактики захворювань та інших принципів, закладених в регламентах (Nuttavuthisit and Thogersen, 2017). Однією з вимог ведення органічного молочного господарства $€$ заборона застосування хімічно синтезованих традиційних ветеринарних лікарських препаратів або антибіотиків із профілактичною метою. Використання антибіотиків дозволяється лише за призначенням ветеринарного лікаря, при цьому період вибракування продукції від тварин, що лікуються, має бути удвічі більшим, ніж традиційний період обмеження використання продукціï (Ahrendsen and Bielik, 2016).

Мета роботи - провести огляд літератури щодо можливого використання бактеріофагів для лікування маститів корів 3 метою одержання екологічнобезпечного молока.

До числа найбільш поширених захворювань корів відноситься мастит (Kukhtyn et al., 2016). Мастит впливає на якість та безпечність молока, знижує рентабельність через витрати на лікування та знищення молока через ризик потрапляння у нього залишків антибіотиків (Bardiau et al., 2016). Незважаючи на цілий ряд заходів контролю, ця хвороба залишається основною причиною економічних втрат у молочній промисловості в усьому світі (Gulmez Saglam et al., 2017).

Особливе значення у виникненні захворювання має мікробний фактор (Heikkila et al., 2018). Відомо, що запальний процес завжди супроводжується інфекцією, причому більша частина запалень викликається потраплянням бактерій ззовні. В основному вони проникають через дійковий канал вимені (Gulmez Saglam et al., 2017).
Мікроорганізми можуть бути безпосередньою причиною виникнення маститу, а також ускладнювати запальні процеси у вимені, що виникають в результаті впливу на молочну залозу несприятливих факторів навколишнього середовища (Kukhtyn et al., 2016; Heikkila et al., 2018). Широкий спектр мікроорганізмів, які можуть викликати мастит, і значне поширення цих бактерій роблять повне викорінення маститів малоймовірним.

Для лікування маститів використовують препарати, які в більшості своїй містять антимікробні речовини, такі як антибіотики, сульфаніламіди, нітрофурани тощо. Загальні переваги антибіотикотерапії включають в себе: швидке усунення бактеріальних патогенів, зниження ймовірності хронічних рецидивів інфекції, антимікробну дію в малих дозах, широкий спектр протимікробної дії (Kazmierczak et al., 2014).

Незважаючи на великий успіх при лікуванні антибіотиками, виникає ряд негативних побічних впливів на організм тварин: вони пригнічують захисні сили організму, викликають морфологічні зміни в тканинах молочної залози, нерідко викликають подразнення епітелію молочних проток і альвеол, призводять до знищення сапрофітної мікрофлори. Їхнє тривале застосування викликає локальну іммунодепресію молочної залози та появу стійких до них рас мікроорганізмів (Ling et al., 2015).

Поява антибіотикорезистентних штамів мікроорганізмів привела до неефективності лікування бактеріальних хвороб у тварин, збільшення захворюваності та смертності i, як наслідок, до тривалого бактеріоносійства (Kozlovska et al., 2017). У багатьох небезпечних збудників маститів (Staphylococcus aureus, Enterococcus spp., Enterobacteriaceae, Pseudomonas aeruginosa, Acinetobacter spp., Mycobacterium tuberculosis) відзначається “ескалація” розвитку резистентності. Все частіше дослідники виявляють множинно-резистентні (multiple drug resistance, MDR), абсолютно-резистентні (extensively drug resistant, XDR) та пан-резистентні ізоляти бактерій (pandrugresistant (PDR) (Nikaido, 2009; Van Acker et al., 2014). Доведено, що бактерії активно обмінюються генетичними детермінантами резистентності. Існує сформована концепція про набори факторів резистентності, властивих конкретним асоціаціям бактерій (резистом) (Wright, 2010), в тому числі - бактерій організму людини (мікробіом) (Sommer et al., 2010).

Основні генетичні механізми, що визначають лікарську стійкість у бактерій, які відносяться до різних таксономічних груп, значно відрізняються (Kovalenko 
et al., 2018). Так, у метицилін-стійких Staphylococcus aureus (MRSA) важливу роль відіграє стафілококова хромосомная касета SCCmec; у Pseudomonas aeruginosa - гени декількох типів еффлюксних насосів, у ентеробактерій - гени бета-лактамаз розширеного спектру (БЛРС). Свій внесок в резистоми окремих видів бактерій вносять також і універсальні механізми стійкості до деяких класів препаратів: так, стійкість до хінолонів формується завдяки наявності точкових мутацій в генах, що кодують ферменти ДНК-гіразу і топоізомеразу IV (Wang et al., 2016). Велику роль у формуванні і поширенні найбільш "успішних" механізмів резистентності грають мобільні генетичні елементи (транспозони, інтегрони, ISелементи, плазміди) і універсальні процеси обміну генетичною інформацією (кон'югація, трансформація, трансдукція, рекомбінація) (Wright, 2010). Таким чином, явище стійкості патогенних бактерій до антибактеріальних препаратів - природний еволюційний феномен, який неможливо зупинити.

Очевидною альтернативою застосування антибактеріальних препаратів при терапії маститів корів є використання високоефективних екологічно безпечних лікарських засобів на основі сировини рослинного, мінерального та тваринного походження.

Одним з напрямків в лікуванні маститу у корів при веденні органічного господарства $\epsilon$ фітотерапія (Karreman, 2007). Терапевтична ефективність лікарських рослин обумовлена наявністю в них болезаспокійливих, стимулюючих, адаптогенних і тонізуючих речовин. Проте фітотерапія не надто поширена в Україні. Причинами цього $є$ недостатня сировинна база культивування лікарських рослин, незручність їх застосування у нативному вигляді в реальних умовах тваринницьких господарств, практично відсутність на ринку ветеринарних фітопрепаратів (Malinowski, 2002).

Поряд 3 фітотерапією в органічному виробництві використовуються такі методи, як гомеопатія, нейротерапія, акупунктура, фізіотерапія, різні види масажу, біорезонансна, магнітна, озонова, музична терапії тощо (Malinowski, 2002).

Одним з методів лікування і профілактики маститу у корів $є$ використання вакцин. Застосування вакцинації корів проти маститу сприяє формуванню набутого імунітету щодо певного збудника і в той же час має низький побічний ефект (Shkreta et al., 2004). На сьогодні поки немає ефективного методу вакцинації корів проти маститу, що пов'язано з великою кількістю мікрофлори, яка відіграє етіологічну роль у виникненні маститу й імунна реакція тварини на введення антигенів недостатньо висока, внаслідок цього невисока напруженість імунної відповіді (Gogoi-Tiwari et al., 2015).

Таким чином, розробка та пошук нових препаратів проти маститу, які активно діють проти антибіотикостійких штамів бактерій та є екологічно безпечними не втрачає актуальності.

Одним 3 результатів такого пошуку є зацікавленість дослідників можливостями терапевтичного використання бактеріофагів - специфічних вірусів, які атакують тільки бактерії і вбивають патогенні мікроорганізми.

Бактеріофаги широко поширені в природі і характеризуються яскраво вираженим тропізмом, тобто властивістю вражати клітини певного виду. Їх виділяють 3 води, грунту, різних харчових продуктів та 3 клітин тканин організмів людини і тварини. Нині виявлені й описані фаги проти різних видів бактерій як патогенних, так і сапрофітних, що здатні рости в аеробних і анаеробних умовах. Оскільки кожний бактеріофаг $є$ специфічним паразитом бактерій окремого виду і розмножується тільки за їх рахунок, то відповідно і фаги знаходять там, де живуть їхні мікробні популяції. На даний момент не існує жодної відомої бактерії, яка б не могла бути ураженою бактеріофагом чи не несла у своєму геномі профаг (інтегровану нуклеїнову кислоту фага) (O’Flaherty et al., 2014).

Донині в зарубіжній і вітчизняній медичній і науковій практиці накопичено значний досвід успішного використання фагів для терапії бактеріальних інфекцій (Dias et al., 2013). Використання бактеріофагів при дотриманні загальноприйнятих принципів дозволяє домогтися значного терапевтичного результату (O’Flaherty et al., 2014).

За сучасними нормами з метою фагової терапії використовуються тільки вірулентні бактеріофаги, тобто такі, розмноження яких відбувається шляхом літичного циклу (Hoshiba et al., 2010). Антибактеріальний ефект препаратів бактеріофагів обумовлений впровадженням генома фага в бактеріальну клітину з подальшим його розмноженням і лізисом інфікованої клітини (Jassim and Limoges, 2017). Фаги, що вийшли в зовнішнє середовище в результаті лізису бактерії, повторно інфікують і лізують інші бактеріальні клітини, діючи до повного знищення патогенних бактерій у вогнищі запалення (Borysowski et al., 2011).

Сучасні препарати бактеріофагів являють собою комплекс поліклональних високовірулентних бактеріальних вірусів, спеціально підібраних проти груп збудників бактеріальних інфекцій, що зустрічаються найчастіше (Wills et al., 2005).

Препарати бактеріофагів вигідно відрізняються від інших лікувальних засобів за низкою істотних властивостей.

Бактеріофаги високо специфічні при лікуванні інфекцій. Більшість фагів є інфекційними тільки для бактерій, що несуть їх комплементарний рецептор, який ефективно визначає діапазон дії препарату (Koskella and Meaden, 2013). Тому вони не впливають на нормальну мікрофлору і не порушують природний баланс внутрішнього середовища організму.

Антибіотикотерапія дуже ефективна при дії на планктонні форми бактерій, однак вона обмежена в лікуванні бактеріальних інфекцій, викликаних бактеріями, які утворюють біоплівку (Kukhtyn et al., 2017). В той же час фаги, забезпечені ферментами (наприклад, EPS-деполімеразою) на зовнішній поверхні капсида, які деградують позаклітинні полімерні речовини (EPS) та диспергуют бактеріальні біоплівки, дозволяючи фагу проникати в бактерії, вбудовані в матрицю EPS (Abedon, 2015). Потомство фагів, що вивільняється після закінчення літичного циклу, по- 
ширюється у глиб біоплівки шляхом видалення бактерій, вбудованих в наступні шари (Hughes et al., 1998). Щоб проникнути в щільні біоплівки, необхідні високі дози антибіотиків, які здатні пригнічувати ріст бактерій, але повна ерадикація зустрічається рідко, відновлення колоній починається відразу після закінчення лікування антибіотиками (Amorena et al., 1999). Дослідники Gabisoniya і ін. (Gabisoniya et al., 2016) в Інституті бактеріофагів Eliava (Тбілісі, Грузія) виявили, що застосування фагів на колоніях in vitro бактеpiй $P$. aeruginosa не тільки запобігло нарощенню біоплівки, а також деградувало вже існуючу. Обробки препаратами фагів усунули біоплівки, утворені $L$. monocytogenes, P. aeruginosa i Staphylococcus epidermidis на поверхні медичних пристроїв (Motlagh et al., 2016). Ці дані дуже важливі для дослідження проблеми хронічих інфекцій, викликаних мікроорганізмами здатними до плівкоутворення.

У природі бактеріофаги і бактерії підтримують тісний зв'язок в постійній рівновазі 3 послідовністю мутацій, які $є$ джерелом безперервних перетворень. Як до антибіотиків, так і до фагів бактерії здатні виробляти стійкість (Donlan, 2009). Наприклад, якщо бактерія модифікує фагові рецептори на своїй поверхні, вона стає стійкою до бактеріофагу. Проте бактеріофаг за тим самим принципом мутації здатний адаптуватися до опору господаря. Цей коеволюційний процес був відомий протягом тривалого часу (Hughes et al., 1998) та знайшов практичне застосування посилення вірулентності й ефективності бактеріофага як терапевтичного агента проти патогенної бактерії. Таким чином, якщо фагостійку бактерію можна побачити під час лікування, легко і швидко отримують in vitro варіант бактеріофага, ефективний проти двох бактеріальних клонів. Вченими доведено, що комбінація клонів двох бактеріофагів в коктейлі створює подвійну адитивну функцію проти Enterococcus faecalis i Escherichia coli та інших бактерій (Koskella and Meaden, 2013).

Однією з переваг фагової терапії є очевидна відсутність шкідливого впливу на організм тварини, тимчасом як антибіотики мають цілий ряд побічних ефектів. (Sulakvelidze and Kutter, 2005). С тільки побоювання щодо можливого шкідливого впливу молекул бактеріальних клітин, які зруйнувалися через фагову активність, зокрема ендотоксини, що виділяються зі стінки бактерії. Проте такі ж самі побічні ефекти виникають при застосуванні антибіотиків (Donlan, 2009).

Бактеріофаги ефективні в монотерапії, але також можуть застосовуватися в комбінації з іншими препаратами, в т. ч. $з$ антибіотиками і пробіотиками.

Бактеріофаги є самовідтворювальними організмами: ДНК бактеріофага вбудовується в хромосому бактерії, в результаті чого бактеріальна клітина починає продукувати сотні бактеріофагів, які уражують бактерії до їх повного знищення. Крім того коли всі бактерії поражені фагами, їхня кількість, як і кількість фагів починає зменшуватися. При відсутності бактерій, необхідних для розмноження фагів, останні швидко виводяться з організму (Kazmierczak et al., 2015).

\section{Висновки}

Сучасна ситуація щодо лікування маститу корів екологічно безпечними методами на фоні зниження ефективності антибіотикотерапії дуже складна та потребує негайного вирішення. Добрі перспективи в якості антимікробної терапії мають бактеріофаги, які ефективні стосовно як чутливих, так і стійких до антибіотиків бактерій. Бактеріофаги мають ряд переваг: специфічність дії, відсутність пригнічення нормальної мікрофлори і алергічної реакції. Крім того, вагомим аргументом на користь доцільності клінічного застосування бактеріофагів є практично повна відсутність побічних ефектів, а отже, і протипоказань.

\section{References}

Abedon, S.T. (2015). Ecology of anti-biofilm agents I: antibiotics versus bacteriophages. Pharmaceuticals, 8(3), 525-558. doi: 10.3390/ph8030525.

Ahrendsen, B.L., \& Bielik, P. (2016). Organic Food Sourcing, Processing and Distribution: A Case of Satisfying a Growing Market. APSTRACT: Applied Studies in Agribusiness and Commerce, 10(1), 1-6.

Amorena, B., Gracia, E., Monzon, M., Leiva, J., Oteiza, C., Perez, M., \& Hernandez-Yago, J. (1999). Antibiotic susceptibility assay for Staphylococcus aureus in biofilms developed in vitro. Journal of Antimicrobial Chemotherapy, 44(1), 43-55. doi: 10.1093/jac/44.1.43.

Bardiau, M., Caplin, J., Detilleux, J., Graber, H., Moroni, P., Taminiau, B., \& Mainil, J.G. (2016). Existence of two groups of Staphylococcus aureus strains isolated from bovine mastitis based on biofilm formation, intracellular survival, capsular profile and agr-typing. Veterinary microbiology, 185, 1-6. doi: 10.1016/j.vetmic.2016.01.003.

Borysowski, J., Lobocka, M., Miedzybrodzki, R., WeberDabrowska, B., \& Gorski, A. (2011). Potential of bacteriophages and their lysins in the treatment of MRSA current status and future perspectives. Biodrugs, 25, 347-355. doi: 10.2165/11595610-000000000-00000.

Dias, R.S., Eller, M.R., Salgado, R.L., da Silva, C.C., \& De Paula, S.O. (2013). The use of phage: therapy, biocontrol and commercial microbiology. Bacteriophages: Biology, Applications and Role in Health and Disease, 1-34.

Donlan, R.M. (2009). Preventing biofilms of clinically relevant organisms using bacteriophage. Trends in microbiology, 17(2), 66-72. doi: 10.1016/j.tim.2008.11.002.

Gabisoniya, T.G., Loladze, M.Z., Nadiradze, M.M., Chakhunashvili, N.K., Alibegashvili, M.G., Tamarashvili, N.G., \& Pushkina, V.A. (2016). Effects of bacteriophages on biofilm formation by strains of Pseudomonas aeruginosa. Applied biochemistry and microbiology, 52(3), 293-297. doi: 10.1134/S0003683816030042.

Gogoi-Tiwari, J., Williams, V., Waryah, C.B., Eto, K.Y., Tau, M., Costantino, P., \& Mukkur, T. (2015). Comparative studies of the immunogenicity and protective potential of biofilm vs planktonic Staphylococcus aureus vaccine against bovine mastitis using non- 
invasive mouse mastitis as a model system. Biofouling, 31(7), 543-554.

Gulmez Saglam, A., Sahin, M., Celik, E., Celebi, O., Akca, D., \& Otlu, S. (2017). The role of staphylococci in subclinical mastitis of cows and lytic phage isolation against to Staphylococcus aureus, Veterinary World, 10(12), 1481-1485. doi: 10.14202/vetworld.2017.14811485.

Heikkila, A. M., Liski, E., Pyorala, S., \& Taponen, S. (2018). Pathogen-specific production losses in bovine mastitis. Journal of Dairy Science, 101(10), 94939504. doi: 10.3168/jds.2018-14824.

Hoshiba, H., Uchiyama, J., Kato, S., Ujihara, T., Muraoka, A., \& Daibata, M. (2010). Isolation and characterization of a novel Staphylococcus aureus bacteriophage, phiMR25, and its therapeutic potential. Arch. Virol., 155, 545-552. doi: 10.1007/s00705-010-0623-2.

Hughes, K.A., Sutherland, I.W., \& Jones, M.V. (1998). Biofilm susceptibility to bacteriophage attack: the role of phage-borne polysaccharide depolymerase. Microbiology, 144(11), 3039-3047. doi: 10.1099/00221287144-11-3039.

Jassim, S.A., \& Limoges, R.G. (2017). Bacteriophage and Antimicrobial Resistance. In Bacteriophages: Practical Applications for Nature's Biocontrol, Springer, Cham. doi: 10.1007/978-3-319-54051-1_2.

Karreman, H.J. (2007). Phytotherapy for dairy cows. Veterinary Herbal Medicine. SG Wynn and BJ Fougere, ed. Mosby, St. Louis, MO.

Kazmierczak, Z., Gorski, A., \& Dąbrowska, K. (2014). Facing antibiotic resistance: Staphylococcus aureus phages as a medical tool. Viruses, 6(7), 2551-2570. doi: $10.3390 / v 6072551$.

Kazmierczak, Z., Gorski, A., \& Dabrowska, K. (2015). Facing antibiotic resistance: Staphylococcus aureus phages as a medical tool. Viruses 7, 1667. doi: $10.3390 / \mathrm{V} 7041667$.

Koskella, B., \& Meaden, S. (2013). Understanding bacteriophage specificity in natural microbial communities. Viruses, 5(3), 806-823. doi: 10.3390/v5030806.

Kovalenko, V.L., Kovalenko, P.L., Ponomarenko, G.V., Kukhtyn, M.D., Midyk, S.V., Horiuk, Y.V., \& Garkavenko, V.M. (2018). Changes in lipid composition of Escherichia coli and Staphylococcus areus cells under the influence of disinfectants Barez ${ }^{\circledR}$, Biochlor ${ }^{\circledR}$ and Geocide ${ }^{\circledR}$. Ukrainian Journal of Ecology, 8(1), 547-550. doi: 10.15421/2018_248.

Kozlovska, I.M., Romanjuk, N.Y., Romanjuk, L.M., Kukhtyn, M.D., Horiuk, Y.V., \& Karpyk, G.V. (2017). The effect of antimicrobial agents on planktonic and biofilm forms of bacteria that are isolated from chronic anal fissures. Regulatory Mechanisms in Biosystems, 8(4), 577-582. doi: 10.15421/021789.

Krystallis, A., \& Chryssohoidis, G. (2005). Consumers' willingness to pay for organic food: Factors that affect it and variation per organic product type. British Food Journal, 107(5), 320-343.

Kukhtyn, M.D., Horyuk, Y.V., Horyuk, V.V., Yaroshenko, T.Y., Vichko, O.I., \& Pokotylo, O.S. (2017). Biotype characterization of Staphylococcus aureus isolated from milk and dairy products of private production in the western regions of Ukraine. Regulatory Mechanisms in Biosystems, 8(3), 384-388.

Kukhtyn, M.D., Kovalenko, V.L., Horyuk, Y.V., Horyuk, V.V., \& Stravskyy, Y.S. (2016). Bacterial biofilms formation of Cattle mastitis pathogens. Journal for veterinary medicine, biotechnology and biosafety, 2(4), 30-32.

Kukhtyn, M., Berhilevych, O., Kravcheniuk, K., Shynkaruk, O., Horyuk, Y., \& Semaniuk, N. (2017). Formation of biofilms on dairy equipment and the influence of disinfectants on them. Eastern-European Journal of Enterprise Technologies, 5(11), 26-33. doi: 10.15587/1729-4061.2017.110488.

Kukhtyn, M., Berhilevych, O., Kravcheniuk, K., Shynkaruk, O., Horyuk, Y., \& Semaniuk, N. (2017). The influence of disinfectants on microbial biofilms of dairy equipment. Eureka: Life Sciences, 5, 11-17. doi: 10.21303/2504-5695.2017.00423.

Lin, D.M., Koskella, B., \& Lin, H.C. (2017). Phage therapy: an alternative to antibiotics in the age of multidrug resistance.World journal of gastrointestinal pharmacology and therapeutics, 8(3), 162. doi: 10.4292/wjgpt.v8.i3.162.

Ling, L.L., Schneider, T., \& Peoples, A.J. (2015) A new antibiotic kills pathogens without detectable resistance. Nature, 517, 455-459. doi: 10.1038/nature14098.

Malinowski, E. (2002). The use of some immunomodulators and non-antibiotic drugs in a prophylaxis and treatment of mastitis. Polish journal of veterinary sciences, 5(3), 197-202.

Motlagh, A.M., Bhattacharjee, A.S., \& Goel, R. (2016). Biofilm control with natural and genetically-modified phages. World Journal of Microbiology and Biotechnology, 32(4), 67. doi:10.1007/s11274-016-2009-4.

Nikaido, H. (2009). Multidrug resistance in bacteria. Annual review of biochemistry, 78, 119-146. doi: 10.1146/annurev.biochem.78.082907.145923.

Nuttavuthisit, K., \& Thøgersen, J. (2017). The importance of consumer trust for the emergence of a market for green products: The case of organic food. Journal of Business $\quad$ Ethics, 323-337. doi: 10.1007/s10551-015-2690-5.

O’Flaherty, S., Paul Ross, R., \& Coffey, A. (2014). Bacteriophage and their lysins for elimination of infectious bacteria. FEMS Microbiol Rev, 33(4), 801-819. doi: 10.1111/j.1574-6976.2009.00176.x.

Shkreta, L., Talbot, B.G., Diarra, M.S., \& Lacasse, P. (2004). Immune responses to a DNA/protein vaccination strategy against Staphylococcus aureus induced mastitis in dairy cows. Vaccine, 23(1), 114-126. doi: 10.1016/j.vaccine.2004.05.002.

Sommer, M., Church, G.M., \& Dantas, G. (2010). Functional characterization of the antibiotic resistance reservoir in the human microflora. Virulence, 1(4), 299303. doi: 10.4161/viru.1.4.12010.

Sulakvelidze, A. \& Kutter, E. (2005). Bacteriophage therapy in humans. In Bacteriophages: Biology and Application. Ed. E. Kutter and A. Sulakvelidze. Boca Raton, FL: The Chemical Rubber Company Press, 381-436.

Van Acker, H., Van Dijck, P., \& Coenye, T. (2014). Molecular mechanisms of antimicrobial tolerance and resistance 
in bacterial and fungal biofilms. Trends in Microbiology, 22(6), 326-333. doi: 10.1016/j.tim.2014.02.001.

Wang, Z., Zheng, P., Ji, W., Fu, Q., Wang, H., Yan, Y., \& Sun, J. (2016). SLPW: A Virulent Bacteriophage Targeting Methicillin-Resistant Staphylococcus aureus In vitro and In vivo. Front. Microbiol., 7, 934. doi: $10.3389 /$ fmicb.2016.00934.

Wills, Q.F., Kerrigan, C., \& Soothill, J.S. (2005). Experimental bacteriophage protection against Staphylococcus aureus abscesses in a rabbit model. Antimicrob.
Agents Chemother, 49, 1220-1221. doi: 10.1128/AAC.49.3.1220-1221.2005.

Wright, G.D. (2010). Antibiotic resistance in the environment: a link to the clinic? Current opinion in microbiology, 13(5), 589-594. doi: 10.1016/j.mib.2010.08.005.

Wright, G.D. (2010). Q\&A: Antibiotic resistance: where does it come from and what can we do about it? BMC biology, 8(1), 123. doi: 10.1186/1741-7007-8-123. 